\title{
THE ANNUAL
}

OF THE

BRITISH SCHOOL AT ATHENS 


\title{
THE ANNUAL
}

\author{
OF THE
}

\section{BRITISH SCHOOL AT ATHENS}

No. 104

2009

\section{THE BRITISH SCHOOL AT ATHENS \\ Published by the Council}


(C) The Council, British School at Athens, 2009 ISSN oo68-2454

Typeset by Mark Heslington, Scarborough, North Yorkshire

Printed and bound in Great Britain

by Remous Ltd, Milbourne Port, Sherborne 


\section{THE BRITISH SCHOOL AT ATHENS}

$(2009)$

PATRON

HRH THE PRINCE OF W.ALFS

DIRECTOR

Professor C. A. Morgax, MA, Co-Editor of the Annual

VICE-PRFSIDFNTS

Professor Sir JohN BOARDML, MA, FBA, FSA

G. CADOGAN, EsQ., MA, FSA

DR H.W. CATIING, CBE, MA, FSA

M.S.F. HOOD, EsQ., MA, FBA, FSA

Sir Michael. Li fineleyx Smith, KCVO, CMG, D.Phil

Professor R.A. ToMIIIsON, MA, FSA, Vice-President

PROFESSOR P.M. WARREX, MA, FBA, FSA

DR M.H. WIENER, FSA

Dr C.K. W'illiais II, FSA

Mr H. SACKETT, MA, Dip.ED., FSA

ThE BRITISH AMBASSADOR IN ATHENS

Professor P.M. Wharex, MA, FBA, FSA, Vice-President

SIR ADAM RIDLEY, MA

DR L. BEIDALI, MA

DR M.J. BOYD, MA, FSASCOT

DR A.W. DLN, MA

DR Z. ARCHBALD, MPhil

Editor of the Annual

Dr N. MOMigliaio, MA, FSA

Chairman: Publication Committee and Editorial Board

DR A.W. JOHNSTON, MA, FSA
COLNCIL

Professor LORD ReNFREW OF KHIMSTHORN, FBA, Chairman

DR S. MOSSILAN, BA, MSC

Professor A.J.N.W. Pr.G, MA, FSA

Dr S. WALltCE, MA, MSC

DR N. SPENCER

Ms J. Отто (Student Representative)

DR R. PAINE (Student Representative)

Honorary Treasurer

DR C. BELI., MA

Chairman of the Fitch Laboratory Committee PROFESSOR I. FREESTONE, FSA, FGS

Editor of Supplementary Volumes/Studies

Dr O. KRZYSzKowSKA, MA, FSA

Secretary

Ms H.B. FIELDS

Plblichtions BOARD

Professor SUSAN AlCOCk, Browx

Proffssor Stelios ANDreol, Thessaloniki

Professor JoOst Crolthel, AmsterdeM

Dr YANNis HaMILaKIS, SOLTHAMPTON

Dr Pali Halstead, Sheffiel.d

Professor Milthades Hatzopollos, KERA, Athfiss

Professor Jldith Herrix, Krsg's Collf.ge

Professor Chris MeE, liNerpoOl

Dr JAMES ROY, NOTHINGHAM

Professor Tony Spanforth, Newcastle l pox Tyne

Professor ANDREW STEVART, U.C. BERkEI.EY

DR IAN WHITBREAD, LEICESTER

And members of the Publications Subcommittee, ex-officio 
ASSISTANT DIRECTOR

R. K. PITt, EsQ., BA, MA

Director OF THE FITCH LABORATORY

DR E. KIRLATZI, BA

SCHOOI. SFCRETARY

Mrs H. R. ClaRK, MBE

Cerator at KNossos

DR R. D. G. Evely, MA

Prof. T. Whitelath (Acting Curator)

LIBRARIAN

Mrs P. WILSON-ZARGANIS, ALAA

Athens:

Odos Souedias $5^{2}$ GR-1 0676 Athens

School Office:

Greece

Fitch Laboratory:

Tel: oo3o-210-721 7482

E-mail: fitchlab@bsa.ac.uk

Friends of the BSA:
London:

Friends of the BSA (UK) Hon. Secretaries:
The Taverna

Villa Ariadne

Knossos, Heraklion

GR-7 14 og Crete

Greece

Senate House

Malet Street

London

WCIE $7 \mathrm{HL}$

Publications:

Dr H.W. Catling

Dunford House

Langford

Lechlade

Glos., GL7 3LA

USA:

The British School at Athens Foundation

Mr L. Hugh Sackett (President)

Groton School

Box 991, Groton, MA o $145^{\circ}$

USA
Tel: $0030-210-7229283$

E-mail: friends@bsa.ac.uk

Tel: $0030-2810-231993$

Fax: $0030-2810-238495$

E-mail: bsaknoso $\left(_{0}\right.$ otenet.gr

Tel: $0030-210-7210974$

Fax: 0030-210-7236560 E-mail: admin@bsa.ac.uk

Tel: $0044-20-78628732$

Fax: 0044-20-7862 8733

E-mail: bsa@sas.ac.uk

E-mail:publications@bsa.ac.uk

WEBSITE - www.bsa.ac.uk

Miss M.-C. Keith 12 , Sovereign Court $5^{1}$ Gillingham Street London SWIV IIS

Tel: $001-978-44^{8} 5205$

Fax: 001 $-978-448234^{8}$

E-mail: hsackett@groton.org 


\section{PUBLICATIONS OF THE BRITISH SCHOOL AT ATHENS}

The following may be obtained from the London office of the School unless otherwise stated.

Annual of the British School at Athens

From the London office: volumes 86-102 (1991 to 2007); Indexes to volumes 49-68 and 69-84.

From Periodicals Service Company (Germantown, NY 12526, USA): volumes 1 to 101 (1894-5 to 20o6) and the Index to volumes $1-32$.

Supplementary Volumes of the Annual

The following are in print:

3 S. Adam, The Technique of Greek Sculpture (1966)

9 J.M. Hussey, The Finlay Papers: A Catalogue (1973)

11 M.R. Popham, L.H. Sackett and P. Themelis, Lefkandi, I: The Iron Age, Text (1980) only available separately

17 M.R. Popham, The Minoan Unexplored Mansion at Knossos: Text (1985) only available

23 M.R. Popham, P.G. Calligas and L.H. Sackett (eds), Lefkandi II. The Protogeometric Building at Toumba. Part II. The excavation of the building, its architecture and finds (1993)

24 I. Tournavitou, The 'Ivory Houses' at Mycenae (1995)

25 K.A. Wardle (ed.), Nea Nikomedeia, I: The Excavation and the Ceramic Assemblage (1996)

26 W. Cavanagh, J. Crouwel, R.W.V. Catling, and G. Shipley, Continuity and Change in a Greek Rural Landscape: The Laconia Survey, I: Methodology and Interpretation (2002)

27 W. Cavanagh, J. Crouwel, R.W.V. Catling, and G. Shipley, Continuity and Change in a Greek Rural Landscape: The Laconia Survey, II: Archaeological Data (1996)

28 J.N. Coldstream and H.W. Catling (eds), Knossos, the North Cemetery: Early Greek Tombs (1997); 4 volumes, not available separately

29 M.R. Popham, Lefkandi, III: Plates (1996)

30 J.M. Cook and R.V. Nicholls, Old Smyma Excavations: The Temples of Athena (1998)

31 M. Panagiotaki, The Central Palace Sanctuary at Knossos (1999)

32 C. Ridley, K.A. Wardle and C.A. Mould, Servia I: Anglo-Hellenic Rescue Excavations 197I-73 directed by Katerina Rhomiopoulou and Cressida Ridley (2000)

33 J.J. Coulton (ed.), The Fort at Phylla, Vrachos: Excavations and Researches at a Late Archaic Fort in Central Euboea (2002)

34 P.A. Mountjoy, with contributions by B. Burke, K.S. Christakis, J.M. Driessen, R.D.G. Evely, C. Knappett and O.H. Krzyzskowska, Knossos: The South House (2003)

35 O. Gilkes (ed.), The Theatre at Butrint: Luigi Maria Ugolini's Excavations at Butrint 1928-1932 (2003)

36 W. Cavanagh, C. Mee and P. James (with contributions by N. Brodie and T. Carter), The Laconia Rural Sites Project $(2005)$

37 K. Francis (ed.), Explorations in Albania, 1930-39: The Notebooks of Luigi Cardini ... (2005)

$3^{8}$ E. Hatzaki, Knossos: The Little Palace (2005)

39 D. Evely (ed.), Lefkandi IV The Bronze Age (2006)

$4^{\circ}$ L. Marangou, C. Renfrew, C. Doumas and G. Gavalas, Markiani, Amorgos: an early Bronze Age fortified settlement (2006)

$4^{1}$ C.F. Macdonald and C. Knappett (with contributions by I. Schoep, J. Weingarten, V. Isaakidou and T. Carter), Knossos: Protopalatial Deposits in early Magazine A and the South-West Houses (2007)

$4^{2}$ C. Renfrew, co-edited by N. Brodie, C. Morris and C. Scarre (with contributions by R.L.N. Barber, J.F. Cherry, J.L. Davis, A. Daykin, R.K. Evans, L. Morgan, P.A. Mountjoy, S.J. Vaughan, D. Williams and N. Winder, et al.), Excavations at Phylakopi in Melos 1974-77 (2007)

43 L.H. Sackett, J.A. MacGillivray and J.M. Driessen (with contributions by C. Doherty, D. Evely, E.M. Hatzaki, D. Mylonas, D. Reese, A. Sarpaki, S.M. Thorne, S. Wall-Crowther and J. Weingarten), Palaikastro: Two Late Minoan Wells (2007) 
44 W.D. Taylour and R. Janko (with the assistance of D. Fortenberry, M.J. Goalen and T. Wallace), Ayios Stephanos: Excavations at a Bronze Age and Medieval Settlement in Southern Laconia (2008)

45 H.W. Catling (with contributions by H. Hughes-Brock, N. Brodie, G. Jones, R.E. Jones and J.E. Tomlinson), Sparta: Menelaion I. The Bronze Age (2009)

\section{BSA Studies}

1 M.R. Popham and M.A.V. Gill, The Latest Sealings from the Palace and Houses at Knossos (1997)

3 E. Adam, G. Bailey, E. Pangopoulou, C. Perlès and K. Zachos (eds), The Palaeolithir of Greece and the Balkans: Proceedings of the ICOPAG Conference, Ioannina, September 1994 (1999)

5 J.A. MacGillivray, Knossos: Pottery Groups of the Old Palace Period (1999)

6 J.A. MacGillivray, J.M. Driessen and L.H. Sackett (eds), The Palaikastro Kouros: A Minoan Chryselephantine Statuette and its Aegean Context (2000)

7 J.N. Coldstream, L.J. Eiring and G. Forster, Knossos Pottery Handbook: Greek and Roman (2001)

8 J. Herrin, M. Mullett and C. Otten-Froux (eds), Mosaic: Festschrift for A. H. S. Megaw (2001)

9 E. Kotjabopoulou, Y. Hamilakis, P. Halstead, C. Gamble, and P. Elefanti (eds), Zooarchaeology in Greece: Recent Advances (2003)

10 N. Galanidou and C. Perlès (eds), The Greek Mesolithic: Problems and Perspectives (2003)

11 M. Iacovou (ed.), Archaeological Field Survey in Cyprus: Past History, Future Potential. Proceedings of a Conference held by the Archaeological Research Unit of the University of Cyprus, I-2 December, 2000 (2004)

12 G. Cadogan, E. Hatzaki and A. Vasilakis (eds), Knossos: Palace, City, State: Proceedings of the Conference in Herakleion organised by the British School at Athens and the 23 rd Ephoreia of Prehistoric and Classical Antiquities of Herakleion, in November 20oo, for the Centenary of Sir Arthur Evans's Excavations at Knossos (2004)

13 L. Morgan (ed.), Aegean Wall Painting: A Tribute to Mark Cameron (2005)

14 N. Momigliano (ed), with chapters by P. Tomkins, D.E. Wilson, N. Momigliano, J.A. MacGillivray and E. Hatzaki, Knossos Pottery Handbook: Neolithic and Bronze Age (Minoan) (2007)

15 R. Westgate, N. Fisher and J. Whitley (eds), Building Communities: Houses, Settlement and Society in the Aegean and Beyond: Proceedings of a Conference held at Cardiff University $17-21$ April 2001 (2007)

16 W.G. Cavanagh, C. Gallow and M. Georgiadis (eds), Sparta and Laconia: from Prehistory to Pre-Modern (2009)

\section{Archaeological Reports}

Some back issues of this annual publication (issued jointly by the School and the Society for the Promotion of Hellenic Studies) may be obtained from the London Office.

Fitch Laboratory Occasional Papers

This series may be obtained from Oxbow Books, Park End Place, Oxford, OX 1 1 H.

(http://www.oxbowbooks.com/) 


\section{CONTENTS}

ABSTRACTS ............................... xiii

EDITOR'S ACKNOWLEDGEMENTS $\ldots \ldots \ldots \ldots \ldots \ldots \ldots \ldots \ldots \ldots \ldots \ldots \ldots \ldots \ldots$ xxii

1. Gerald Cadogan: Nicolas Coldstream $(1927-2008) \ldots \ldots \ldots \ldots \ldots \ldots$

2. K.D. Francis, D.J. Bescoby AND I. GjIPALI: A Preliminary Investigation of Two Prehistoric Cave Sites in Southern Albania . . . . . . . . . . . . . . . .

3. C. Renfrew; O. Phil aniotol, N. Brodie and G. Gavalas: The Early Cycladic Settlement at Dhaskalio, Keros: Preliminary Report of the 2008 Excavation Season . . . . . . . . . . . . . . . . . . . . . .

4. NeIl. Brodie: A Reassessment of Mackenzie's Second and Third Cities at

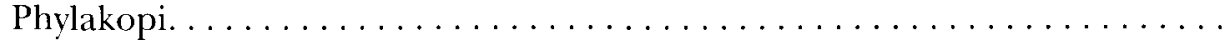

5. P.A. Mouxtjoy: The Late Minoan II-III and Mycenaean Pottery from the 1911 Excavations at Phylakopi on Melos.................

6. INA Berg: X-Radiography of Knossian Bronze Age Vessels: Assessing our Knowledge of Primary Forming Techniques $\ldots \ldots \ldots \ldots \ldots \ldots \ldots$

7. E.B. French aNo Ph. Stockhammer (With a contribltion by U. DammMeinhardT): Mycenae and Tiryns: the Pottery of the Second Half of the Thirteenth Century $\mathrm{BC}-$ Contexts and Definitions . . . . . . . . . .

8. L. Papazoglol-Manioldaki, A. Nafplioti, J.H. Mlsgrave, R.A.H. Neave, D. SmIth AND A.J.N.W. PraG: Mycenae Revisited Part 1. The Human Remains from Grave Circle A: Stamatakis, Schliemann and Two New Faces from Shaft Grave VI . . . . . . . . . . . . . . . .

9. Argyro NAfPlioti: Mycenae Revisited Part 2. Exploring the Local versus Non-local Geographical Origin of the Individuals from Grave Circle A: Evidence from Strontium Isotope Ratio $\left({ }^{8} \mathrm{Sr} /{ }^{86} \mathrm{Sr}\right)$ Analysis . . . . . . . . .

10. A.S. Bolwman, K.A. Brown, T.A. Brown, E.R. Chilvers, R. Arnott and A.J.N.W. PRAG: Kinship in Aegean Prehistory? Ancient DNA in Human Bones from Mainland Greece and Crete . . . . . . . . . . . . . . 
1 1. Elena Konstantinidi-Syvridi and Maria Kontaki: Casting Finger Rings in Mycenaean Times: Two Unpublished Moulds at the National

Archaeological Museum, Athens. . . . . . . . . . . . . . . . .

12. R. Hope SimpSon: Prehistoric Laconia: A Note on the Location of the Site

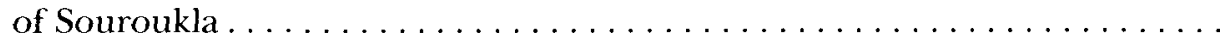

13. Gina Salapata: Female Triads on Laconian Terracotta Plaques...........

14. Tyler Jo Smith: East Greek Pottery in the Collection of the British School

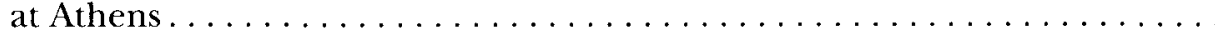

INDEXEs by Graham Shipley. . . . . . . . . . . $\ldots \ldots \ldots \ldots \ldots \ldots \ldots \ldots$

INSTRUCTIONS TO CONTRIBUTORS $\ldots \ldots \ldots \ldots \ldots \ldots \ldots \ldots \ldots \ldots \ldots \ldots \ldots \ldots$ 


\section{ALPHABETICAL TABLE OF CONTENTS}

INA BeRG: X-Radiography of Knossian Bronze Age Vessels: Assessing our

Knowledge of Primary Forming Techniques $\ldots \ldots \ldots \ldots \ldots \ldots \ldots$

A.S. Bolwmay, K.A. Brown, T.A. Brown, E.R. Chilvers, R. ARnotT ANd A.J.N.W. PraG: Kinship in Aegean Prehistory? Ancient DNA in Human Bones from Mainland Greece and Crete. .........................

NeII. Brodik: A Reassessment of Mackenzie's Second and Third Cities at

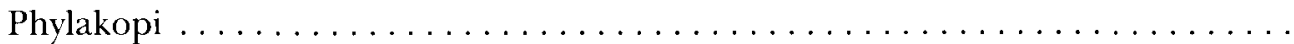

Gerald CADOGan: Nicolas Coldstream $(1927-2008) \ldots \ldots \ldots \ldots \ldots \ldots \ldots$

K.D. Francis, D.J. Bescoby and I. GJipali: A Preliminary Investigation of Two Prehistoric Cave Sites in Southern Albania ......................

E.B. French and Ph. Stockhammer (with a contribution by U. DammMeINHARDT): Mycenae and Tiryns: the Pottery of the Second Half of the Thirteenth Century BC - Contexts and Definitions $\ldots \ldots \ldots \ldots \ldots \ldots$

R. Hope SIMPSOn: Prehistoric Laconia: A Note on the Location of the Site of

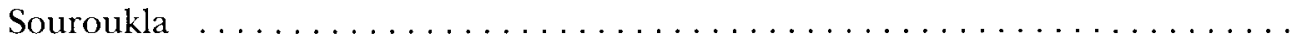

Elena Konstavtinidi-Syvridi and Maria Kontaki: Casting Finger Rings in Mycenaean Times: Two Unpublished Moulds at the National Archaeological

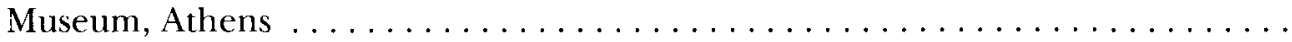

P.A. Mountjoy: The Late Minoan II-III and Mycenaean Pottery from the 1911 Excavations at Phylakopi on Melos............................

ARgYro NAFPLIOTI: Mycenae Revisited Part 2. Exploring the Local versus Non-local Geographical Origin of the Individuals from Grave Circle A: Evidence from Strontium Isotope Ratio $\left({ }^{8} \mathrm{Sr} /{ }^{86} \mathrm{Sr}\right)$ Analysis . . . . . . . . . .

L. Papazoglou-Manioudaki, A. Nafplioti, J.H. Musgrave, R.A.H. Neave, D. Smith and A.J.N.W. Prag: Mycenae Revisited Part 1. The Human Remains from Grave Circle A: Stamatakis, Schliemann and Two New Faces from Shaft

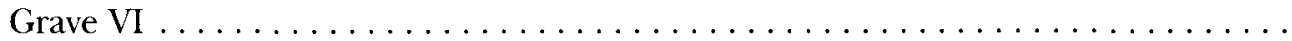


C. Renfrew, O. Philaniotou, N. Brodie and G. Gavalas: The Early Cycladic Settlement at Dhaskalio, Keros: Preliminary Report of the 2008 Excavation

Season ............................................

Gina SaLAPata: Female Triads on Laconian Terracotta Plaques............

Tyler Jo Smith: East Greek Pottery in the Collection of the British School

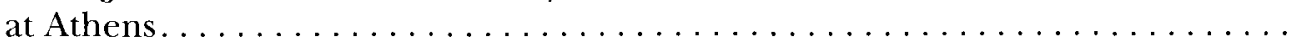

